\title{
Pengaruh sudut kemiringan atap seng dan plastik gelombang terhadap tingkat kebisingan akibat air hujan
}

\section{Qiram*, G. Rubiono}

Teknik Mesin, Fakultas Teknik, Universitas PGRI Banyuwangi, Jl. Ikan Tongkol 22 Banyuwangi, Jawa Timur 68416, Indonesia, Telp. (0333)421593, 423639

*Email: ikhwanulqiram@gmail.com

\section{ARTICLE INFO}

Article History:

Received 02 June 2016

Accepted 02 August 2016

Available online 30 December 2016

\section{Keywords:}

Zinc roof

Plastic roof

Inclination angle

Noise

\begin{abstract}
Zinc and plastic roofs are used vary widely in poor society because of their low price and their installation easiness. A roof installation with an inclination angle is done in order to the rain water is easy to flow. Rainfall causes noise that has a bad impact to human. This research is aimed to obtaining the effect of inclination angle of zinc and plastic roofs on the noise intensity. The research was done experimentally. The roofs investigated consist of zinc and plastic roofs in waveforms. A room with an overall size of $80 \mathrm{~cm} \times 80 \mathrm{~cm} \times 150 \mathrm{~cm}$ was made of wood as the frame. The inclination angles were varied; $10^{\circ}, 20^{\circ}, 30^{\circ}$ and $40^{\circ}$. The rainfall was modeled by a sprayer with three different water flow rates 0,$8 ; 1,0$ and 1,2 lt/s. These flow rates represented low, medium and heavy rains. The noise intensity was measured using a sound level meter, which was placed in the centre of the room. The result shows that increasing the roof inclination angle causes the noise intensity to decrease. The plastic roof has lower noise intensity than the zinc roof. Furthermore, the experimental noise intensity data are relatively safe according to the noise safety level.
\end{abstract}

\section{PENDAHULUAN}

Atap seng dan plastik gelombang banyak digunakan masyarakat golongan ekonomi menengah ke bawah. Menurut Kementrian Sosial RI dan Badan Pusat Statistik, 2012, kondisi fisik serta fasilitas tempat tinggal Rumah Tangga Sangat Miskin (RTSM) salah satunya diindikasikan rumah yang atapnya terbuat dari ijuk/ rumbia atau genteng/seng/asbes dengan kondisi tidak baik/kualitas rendah. Perkembangan jumlah dan prosentase penduduk sangat miskin adalah sebagai berikut:Rumah yang sehat adalah rumah yang dapat memenuhi kebutuhan jasmani (fisik) dan rohani (psikis). Selain itu rumah sehat adalah rumah yang dapat digunakan sebagai tempat berlindung terhadap penularan penyakit dan gangguan atau kecelakaan (Sunarsih E, 2014). Atap seng digunakan karena murah dan mudah pemasangannya. Konstruksi yang sederhana dimaksudkan agar air hujan dapat mengalir dengan baik. Agar air hujan yang tertampung bisa mengalir, maka atap dibuat miring ke salah satu sisi dengan kemiringan yang cukup. Sedangkan atap plastik gelombang digunakan dengan alasan pencahayaan ruangan karena 
sifat bahan ini yang tembus cahaya. Metode pemasangan 2 jenis atap ini lebih didasarkan pada kesesuaian dengan aliran air hujan.

Atap seng dan plastik gelombang menimbulkan kebisingan akibat hujan. Kebisingan akibat air hujan yang jatuh di atap logam merupakan masalah yang umum terjadi (Wardle Storeys Blackburn Ltd, 2008). Jumlah curah hujan rata-rata yang turun di berbagai tempat di wilayah Indonesia dalam setahun berkisar antara $500 \mathrm{~mm}$ sampai lebih dari 5000 $\mathrm{mm}$ (Tukidi, 2010). Banyak sedikitnya curah hujan juga dipengaruhi oleh letak dan ketinggian suatu tempat, yakni tempat-tempat yang letaknya di pantai barat atau selatan yang langsung menghadapi angin barat memiliki curah hujan yang besar.

Jansen HW (2004) meneliti kebisingan atap logam (genteng logam) dengan sudut pemasangan $30^{\circ}$. Atap diposisikan di atas ruangan dengan rangka kayu dan dinding panel kayu. Pengukuran intensitas suara dilakukan dengan mikrofon yang dipasang tetap di dalam ruangan dan sebuah mikrofon berputar di luar ruangan. Hasil pengukuran menunjukkan tingkat kebisingan sebesar 88-96 dB.

Hopkins C (2006) meneliti kebisingan ruangan akibat hujan dilakukan terhadap atap logam ringan. Pengukuran dilakukan dengan pemodelan hujan lebat menggunakan diameter lubang aliran air hujan sebesar $5 \mathrm{~mm}$. Hasil pengukuran menunjukkan tingkat kebisingan pada kisaran 52-68,7 dB. Hasil penelitian Ikeda $\mathrm{H}$, et al (2002) menunjukkan bahwa atap baja yang menggunakan bahan peredam dapat mengurangi kebisingan sekitar $3 \mathrm{~dB}$. Kristanto L (2011) melakukan studi reduksi bunyi pada material insulasi atap zincalume meliputi insulasi cat atap (Orca zinc coat), glasswool-rockwool dan styrofoam. Hasil pengujiannya menunjukkan bahwa penggunaan coating dapat mereduksi bunyi rata-rata sebesar $4 \mathrm{~dB}$.

Rosadi HE (2012) melakukan penelitian menggunakan simulasi dengan program Ecotech untuk menentukan suhu yang dihasilkan dari sudut kemiringan atap yang sering digunakan seperti $35^{\circ}, 45^{\circ}$ dan $55^{\circ}$. Analisis dilakukan secara kualitatif dengan sistem perbandingan. Hasil penelitian menunjukkan bahwa semakin besar sudut kemiringan atap maka semakin dingin suhu yang dihasilkan di dalam ruangan. Sudut $45^{\circ}$ dengan arah hadap timur barat merupakan sudut kemiringan atap yang ideal untuk menghasilkan kenyaman termal pada bangunan.

Penelitian ini bertujuan untuk mendapatkan pengaruh sudut kemiringan atap seng dan plastik gelombang terhadap tingkat kebisingan akibat air hujan. Hal ini dilakukan karena dampak terhadap kebisingan atap seng dan plastik gelombang berpotensi pada gangguan kesehatan atau pendengaran pada golongan masyarakat miskin yang berjumlah relatif besar. Metode pemasangan atap seng dan plastik gelombang yang mempertimbangkan aspek kebisingan diharapkan dapat mengurangi tingkat kebisingan yang pada akhirnya dapat mengurangi dampak yang lebih luas.

\section{Atap Seng dan Plastik Gelombang}

Atap merupakan bagian dari bangunan gedung (rumah) yang letaknya berada di bagian paling atas, sehingga untuk perencanaannya haruslah diperhitungkan. Karena dilihat dari penampakannya ataplah yang paling pertama kali terlihat oleh pandangan setiap yang memperhatikannya. Untuk itu perencanaan bentuk atap harus mempunyai daya arstistik. Bisa juga dikatakan bahwa atap merupakan mahkota dari suatu bangunan rumah. Atap sebagai penutup seluruh ruangan yang ada di bawahnya, sehingga akan terlindung dari panas, hujan, angin dan binatang buas serta keamanan. Atap merupakan bagian dari struktur bangunan yang berfungsi sebagai penutup/pelindung dari panas terik matahari dan hujan sehingga memberikan kenyamanan bagi penggunaan bangunan (Zikri A, 2014).

Bentuk atap berdasarkan kemiringan adalah sebagai berikut:

1. Atap Datar (Kemiringan $0^{\circ}-4^{\circ}$ ).

- Sederhana dari segi pembuatan dan penampakkannya.

- Biaya per $\mathrm{m}^{2}$ lebih murah (pemakaian bahan lebih hemat).

- Ruangan cenderung panas karena umumnya atap datar menggunakan bahan metal (mempunyai penyaluran panas yang rendah sehingga panas matahari langsung dialirkan ke dalam ruang);

- Ada 2 jenis penutup, yaitu atap beton dan atap metal. Atap beton lebih mahal tetapi penyaluran panasnya lebih tinggi.

2. Atap Miring, (tinggi atap sama dengan atau lebih dari setengah lebar bangunan).

- Konstruksi atap lebih rumit;

- Membutuhkan jumlah material yang lebih banyak;

- Ruang di bawah lebih dingin karena adanya rongga di dalamnya;

- Pilihan bahan ada 2 yaitu tanah liat (genteng) dan bahan pengganti seperti beton, bitumen, kayu keras (sirap), dan 
lembaran baja tipis yang dibentuk seperti genteng;

- Pilihan model atap: pelana, perisai, kerucut, kombinasi beberapa tipe.

Atap seng terbuat dari lembaran baja tipis yang diberi lapisan seng secara elektrolisis yang tujuannya untuk membuatnya jadi tahan karat. Jadi, kata 'seng' berasal dari bahan pelapisnya. Jenis ini akan bertahan selama lapisan seng ini belum hilang. Jika sudah lewat masa itu, atap akan mulai berkarat dan bocor.

\section{Kebisingan}

Kebisingan berasal dari kata bising yang artinya semua bunyi yang mengalihkan perhatian, mengganggu, atau berbahaya bagi kegiatan sehari-hari. Bising, umumnya didefisinisikan sebagai bunyi yang tidak diinginkan dan juga dapat menyebabkan polusi lingkungan. Suara adalah sensasi atau rasa yang dihasilkan oleh organ pendengaran manusia, ketika gelombang-gelombang suara dibentuk di udara sekeliling manusia melalui getaran yang diterimanya (Wafiroh AH, 2013). Bising didefinisikan sebagai suara yang dihasilkan oleh gelombang akustik dengan intensitas dan frekuensi yang acak (Munilson J, et. al, 2014). Kebisingan adalah bunyi yang tidak diinginkan atau bunyi yang menyakitkan telinga (Kristanto L, et. al, 2011).

Keputusan Menteri Lingkungan Hidup tahun 1996 mendefinisikan, bahwa kebisingan adalah bunyi yang tidak diinginkan dari usaha atau kegiatan dalam tingkat dan waktu tertentu yang dapat menimbulkan gangguan kesehatan manusia dan kenyamanan lingkungan. Kebisingan juga didefinisikan sebagai getarangetaran yang tidak teratur, dan memperlihatkan bentuk yang tidak biasa. Faktor-faktor yang mempengaruhi antara lain adalah pola intensitas, frekuensi dan pembangkitan. Kebisingan itu sendiri biasanya dianggap sebagai bunyi yang tidak dikehendaki. Bunyi terjadi ketika telinga manusia mendengar pada tekanan kecil yang naik turun di udara, yang disebabkan oleh pergerakan getaran dari benda padat.

Alat ukur standar untuk kebisingan adalah sound level meter (SLM). SLM dapat mengukur 3 jenis karakter respon frekuensi, yang ditunjukkan dalam skala A, B, dan C. Skala A ditemukan paling mewakili batasan pendengaran manusia dan respons telinga terhadap kebisingan, termasuk kebisingan akibat lalu lintas, serta kebisingan yang dapat menimbulkan gangguan pendengaran. Skala A dinyatakan dalam satuan dBA (Yermadona $\mathrm{H}$ et al, 2013).
Perhitungan tingkat kebisingan dilakukan dengan menggunakan tingkat kebisingan ekuivalen (Leq) menggunakan persamaan sebagai berikut (Fredianta D, et al, 2013):

$$
\begin{aligned}
L_{e q}= & 10 \log \left\{f_{1} 10^{0,1 L_{1}}+f_{2} 10^{0,1 L_{2}}\right. \\
& +\cdots+f_{n} 10^{0,1 L_{n}}
\end{aligned}
$$

Dimana:

$L_{e q}=$ kebisingan ekuivalen $(\mathrm{dB})$

$f_{n}=$ fraksi waktu pengukuran

$L_{n}=$ tingkat bunyi hasil pengukuran $(\mathrm{dB})$

Tabel 1. Parameter Pemodelan Hujan (Hopkins C, 2006)

\begin{tabular}{llll}
$\begin{array}{l}\text { Rainfall } \\
\text { type }\end{array}$ & $\begin{array}{l}\text { Rainfall } \\
\text { rate } \\
(\mathrm{mm} / \mathrm{h})\end{array}$ & $\begin{array}{l}\text { Volume } \\
\text { median } \\
\text { drop } \\
\text { diameter } \\
(\mathrm{mm})\end{array}$ & $\begin{array}{l}\text { Fall } \\
\text { velocity } \\
(\mathrm{m} / \mathrm{s})\end{array}$ \\
\hline Intense & 15 & 2 & 4 \\
Heavy & 40 & 5 & 7 \\
\hline
\end{tabular}

\section{Gangguan Akibat Kebisingan}

Kebisingan dapat menyebabkan berbagai gangguan fisiologis, psikologis, komunikasi dan pendengaran (Feidihal, 2007). Gangguan fisiologis dapat menimbulkan kelelahan, dada berdebar, menaikkan denyut jantung, mempercepat pernafasan, pusing, sakit kepala dan kurang nafsu makan. Gangguan psikologis dapat berupa rasa tidak nyaman, kurang konsentrasi, rasa jengkel, khawatir, cemas, susah tidur, mudah marah dan cepat tersinggung.

Gangguan pendengaran akibat kebisingan dapat terjadi secara mendadak maupun secara perlahan. Gangguan ini dapat terjadi dalam kurun waktu bulan sampai tahun. Hal ini sering tidak disadari oleh penderitanya, sehingga pada saat penderita mulai mengeluh, biasanya sudah dalam stadium yang tidak dapat disembuhkan. Pada kasus-kasus tertentu, gangguan pendengaran akibat bising mulai berlangsung antara 6 sampai 10 tahun setelah terpajan bunyi yang keras (Munilson J, et. al, 2014).

Tingkat ketergangguan manusia oleh kebisingan dibagi menjadi 5 skala verbal, dimana nilai 1 menandakan responden tidak terganggu dan nilai 5 menandakan sangat terganggu.

Tabel 2. Skala tingkat ketergangguan (Sembiring EL, Surbakti MS, 2013)

\begin{tabular}{cl}
\hline Skala & \multicolumn{1}{c}{ Tingkat Ketergangguan } \\
\hline 1 & Tidak terganggu \\
2 & Rendah \\
\hline
\end{tabular}




\begin{tabular}{ll}
\hline 3 & Sedang \\
4 & Terganggu \\
5 & Sangat terganggu \\
\hline
\end{tabular}

Kebisingan dapat menimbulkan dampak buruk bagi manusia. Kekerasan bunyi sebesar 30-65 dB yang diterima secara terus-menerus akan mengganggu selaput telingga dan menyebabkan gelisah. Pada kisaran 65-90 dB akan merusak lapisan vegetatif manusia (jantung, peredaran darah dan lain-lain). Bila bising mencapai kisaran 90-130 dB akan merusak telinga (Setiawan MF, 2010).

Bising yang cukup keras di atas $70 \mathrm{~dB}$ dapat menyebabkan kegelisahan, kurang enak badan, kejenuhan mendengar, sakit labung dan masalah peredaran darah. Bising yang sangat komunikasi dan gangguan tidur. Sedangkan pengaruh bising secara psikologis, yaitu berupa penurunan efektivitas kerja dan kinerja. Tingkat kebisingan $80,3 \mathrm{~dB}$ dan $85 \mathrm{~dB}$ produktivitas mengalami penurunan sebesar $12 \%$ (Sembiring EL, Surbakti MS, 2013).

\section{Ambang Batas Kebisingan Rumah}

Hasil kesepakatan para ahli mengemukakan bahwa batas toleransi untuk pemaparan bising selama 8 jam perhari, sebaiknya tidak melebihi ambang batas $85 \mathrm{dBA}$. Dampak kebisingan paling jelas adalah untuk pendengaran. WHO (World Health Organization) menilai angka kebisingan yaitu sebesar $70 \mathrm{dBA}$ sebagai tingkat kebisingan maksimum yang aman di tempat kerja. Di atas tingkat kebisingan ini, pelindung pendengaran harus dipakai. Para ahli menyarankan bahwa ambang nyeri dicapai

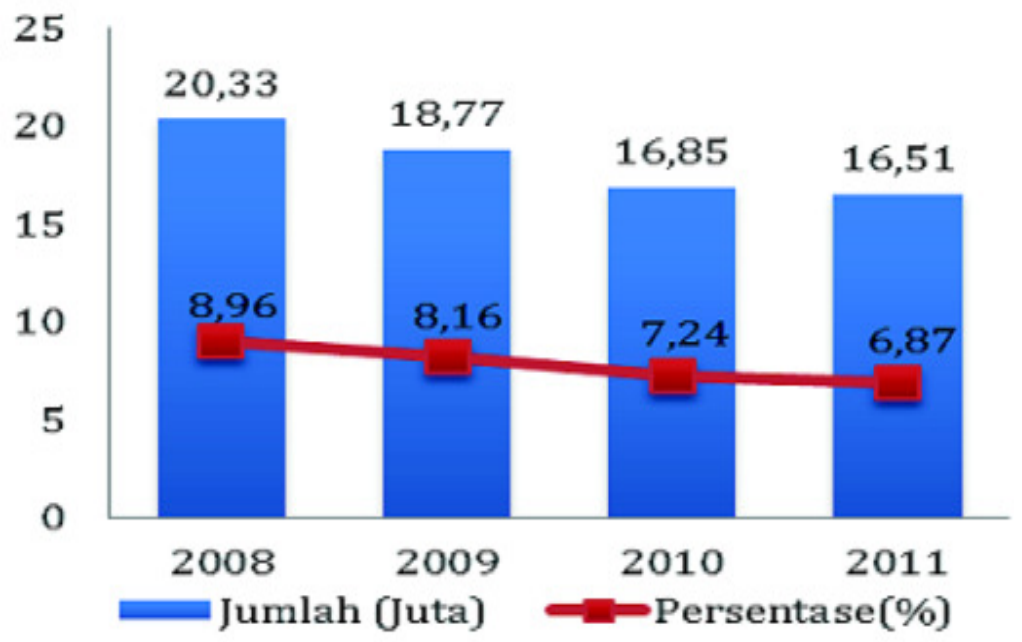

Gambar 1. Perkembangan penduduk sangat miskin di Indonesia (Kementrian Sosial RI dan Badan Pusat Statistik, 2012)

keras (di atas $85 \mathrm{~dB}$ ) bila berlangsung lama dapat menyebabkan kehilangan pendengaran secara sementara ataupun permanen. Efek kebisingan terhadap kesehatan menurut WHO adalah gangguan kemampuan berbicara dan gangguan komunikasi, gangguan mendapatkan informasi, gangguan tidur dan kerusakan pendengaran.

Pengaruh kebisingan secara fisik tidak saja menganggu organ pendengaran, tetapi juga dapat menimbulkan gangguan pada organ-organ tubuh yang lain, seperti penyempitan pembuluh darah dan sistem jantung. Umumnya masalah yang terkait dengan kebisingan adalah gangguan pada tingkat kebisingan 120 dBA dan 140 dBA sebagai bahaya paling ekstrem (Kristanto L, et. al, 2011).

Tabel 3. Kriteria bising latar belakang yang direkomendasikan untuk rumah tinggal (Setiawan MF, 2010)

\begin{tabular}{ccc}
\hline Lokasi & $\begin{array}{c}\text { Ruang } \\
\text { Tidur } \\
\text { (dB) }\end{array}$ & $\begin{array}{c}\text { Ruang } \\
\text { Keluarga } \\
\text { (dB) }\end{array}$ \\
\hline Desa & 20 & 25 \\
Pinggiran kota & 25 & 30 \\
\hline
\end{tabular}




\begin{tabular}{ccc}
\hline Kota & 30 & 35 \\
Dekat lalu lintas padat & 35 & 40 \\
Dekat industri padat & 40 & 45
\end{tabular}

Studi menunjukan bahwa kebisingan stabil di atas $50 \mathrm{dBA}$ menjadi gangguan moderat dan di atas $55 \mathrm{dBA}$ merupakan gangguan serius di rumah. Untuk kesehatan dan keselamatan di lingkungan non kerja $55 \mathrm{dBA}$ ditetapkan sebagai tingkat yang aman (Kristanto L, et. al, 2011). Tingkat kebisingan yang diperkenankan di lingkungan rumah tinggal antara lain untuk kamar tidur sebesar $25 \mathrm{dBA}$ dan ruang keluarga sebesar 40 dBA (Satwiko P, 2012). Sumber lain menyatakan kebisingan di rumah maksimal sebesar $50 \mathrm{~dB}$ dan di kamar tidur maksimal sebesar 30 dB (Sunarsih E, 2014).

\section{METODOLOG}

\section{Variabel Penelitian}

Variabel bebas meliputi jenis atap (seng gelombang dan plastik gelombang), debit aliran sebagai model hujan $(0,8 ; 1,0$ dan $1,2 \mathrm{lt} / \mathrm{dt})$ dan sudut kemiringan atap $\left(10^{\circ}, 20^{\circ}, 30^{\circ}\right.$ dan $\left.40^{\circ}\right)$. Variabel terikat yaitu intensitas bunyi (dB).
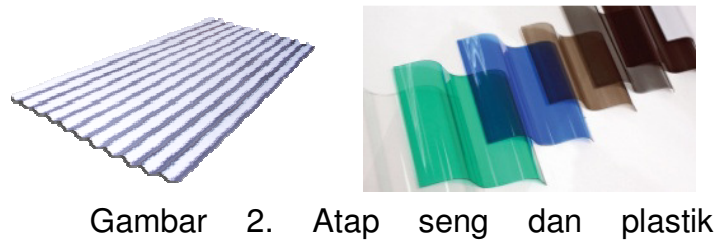

gelombang

Gambar 2. Atap seng dan plastik

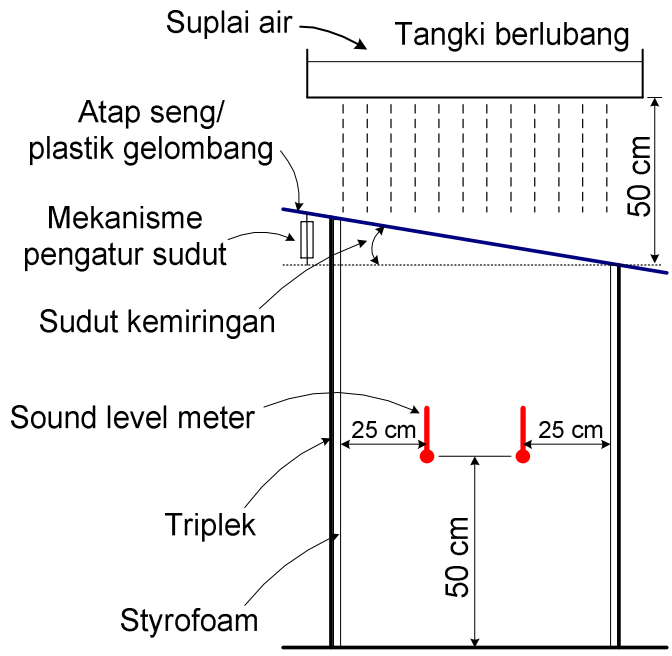

Gambar 3. Skema Peralatan Penelitian
Penelitian dilakukan dengan membuat model ruangan berukuran panjang $80 \mathrm{~cm}$, lebar $80 \mathrm{~cm}$ dan tinggi $150 \mathrm{~cm}$. Ruangan dibuat dengan rangka kayu. Tangki pemodelan hujan dengan lubang diameter $5 \mathrm{~mm}$. Dinding dilapisi dengan triplek dan dilapisi styrofoam untuk peredam suara. Pengaturan sudut kemiringan atap dilakukan dengan sebuah mekanisme pengatur. Data kebisingan diukur menggunakan sound level meter pada 2 titik pengukuran seperti terlihat pada skema di gambar 3. Salah satu bagian dinding ruangan alat diberi lubang intip untuk pembacaan data dengan melapis lubang tersebut dengan kaca. Waktu diukur dengan stopwatch.

\section{Langkah Pengujian}

Pengambilan data dilakukan dengan langkah-langkah sebagai berikut:

1. Persiapan alat, atap seng gelombang dipasang pada sudut kemiringan $10^{\circ}$.

2. Air dialirkan menggunakan pompa ke tangki pemodelan hujan. Aliran dibiarkan beberapa saat sampai kondisinya stabil.

3. Pengambilan data dilakukan dengan mencatat intensitas bunyi di sound level meter. Pencatatan dilakukan selama 2,5 menit (150 detik) dengan selang 30 detik.

4. Mengulangi percobaan untuk sudut kemiringan yang lain.

5. Mengulangi percobaan untuk atap plastik gelombang.

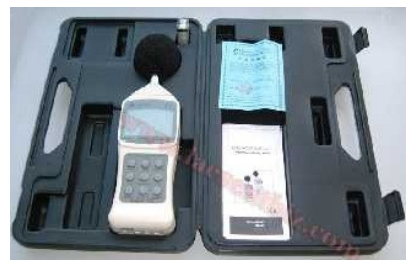

Gambar 4. Sound level meter (Wafiroh AH, 2013)

\section{HASIL DAN PEMBAHASAN}

Hasil pengambilan data pada 2 titik pengukuran dihitung nilai rata-ratanya. Hasil perhitungan dapat dilihat pada tabel 4 dan 5 .

Tabel 4. Data seng gelombang

\begin{tabular}{|c|c|c|c|}
\hline \multirow{2}{*}{$\begin{array}{c}\text { Sudut } \\
\text { Kemiringan }\left({ }^{\circ}\right)\end{array}$} & \multicolumn{3}{|c|}{ Kebisingan rata-rata (dB } \\
\hline & $\begin{array}{c}\text { Debit } \\
0,8 \mathrm{lt} / \mathrm{dt}\end{array}$ & $\begin{array}{c}\text { Debit } \\
1,0 \mathrm{lt} / \mathrm{dt}\end{array}$ & $\begin{array}{c}\text { Debit } \\
1,2 \mathrm{lt} / \mathrm{dt}\end{array}$ \\
\hline
\end{tabular}




\begin{tabular}{cccc}
\hline 10 & 80.86 & 82.12 & 83.46 \\
20 & 79.62 & 80.94 & 82.68 \\
30 & 78.53 & 79.46 & 81.20 \\
40 & 76.98 & 78.18 & 80.22 \\
\hline \multirow{3}{*}{ Tabel 5. Data plastik gelombang } \\
\hline \multirow{2}{*}{ Sudut } & \multicolumn{3}{c}{ Kebisingan rata-rata (dB) } \\
\cline { 2 - 4 } Kemiringan $\left({ }^{\circ}\right)$ & Debit & Debit & Debit \\
& $0,8 \mathrm{lt} / \mathrm{dt}$ & $1,0 \mathrm{lt} / \mathrm{dt}$ & $1,2 \mathrm{lt} / \mathrm{dt}$ \\
\hline 10 & 79.84 & 81.45 & 82.86 \\
20 & 78.72 & 80.72 & 82.14 \\
30 & 77.24 & 78.93 & 79.34 \\
40 & 75.96 & 77.26 & 78.14 \\
\hline
\end{tabular}

selanjutnya digunakan untuk menghitung tingkat kebisingan ekuivalen. Contoh perhitungan untuk data seng gelombang dengan sudut kemiringan $10^{\circ}$ dan debit $0,8 \mathrm{lt} / \mathrm{dt}$ didapat nilai rata-rata $f=\frac{30}{150}=0,2$

Sehingga:

$$
\begin{aligned}
L_{e q} & =10 \log \left(0,2 \times 10^{0,1 \times 80,86}\right) \\
& =73,87 \mathrm{~dB}
\end{aligned}
$$

Dengan cara yang sama didapat hasil perhitungan tingkat kebisingan ekuivalen sebagai berikut: Grafik hasil perhitungan pada gambar 5 menunjukkan bahwa semakin besar sudut kemiringan atap maka nilai intensitas bunyi ratarata cenderung semakin menurun. Hal ini disebabkan karena semakin besar sudut kemiringan atap akan menyebabkan benturan air dengan penampang atap akan semakin kecil. Selain itu, semakin besar debit aliran maka tingkat kebisingan rata-rata juga semakin besar. Hal ini sesuai dengan pemodelan debit aliran sebagai representasi model hujan. Semakin

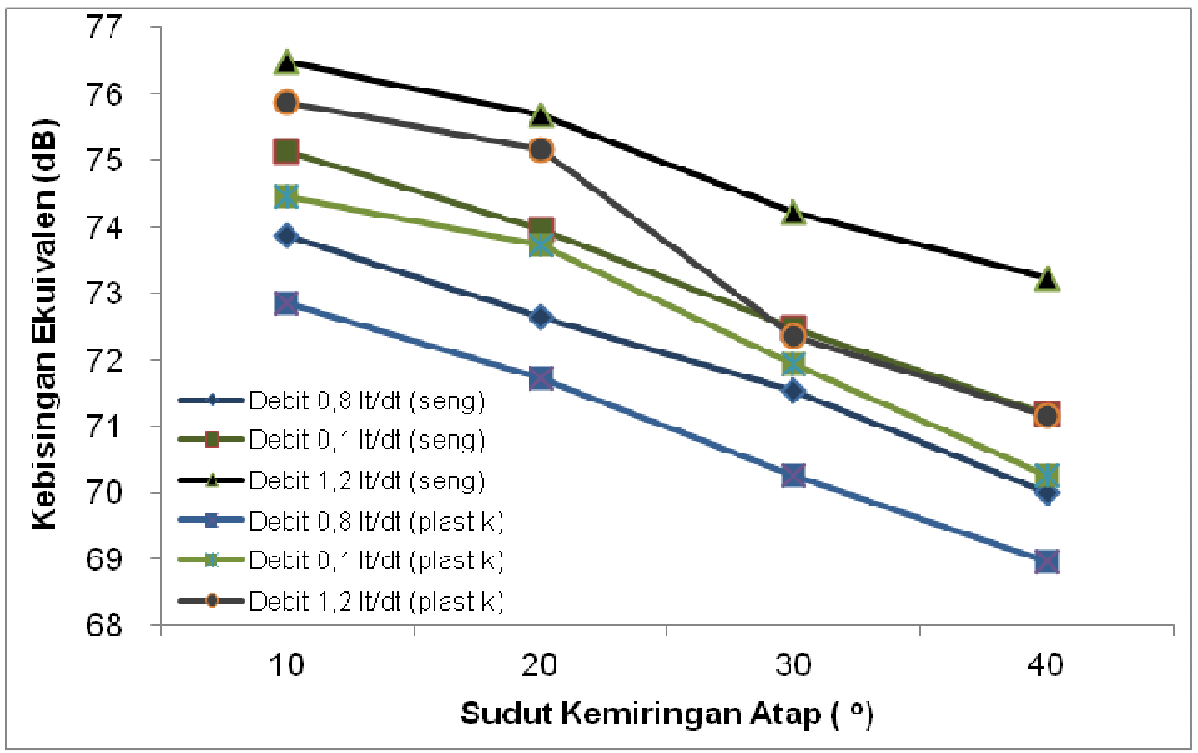

Gambar 5. Hubungan sudut kemiringan atap dengan kebisingan ekuivalen

sebesar 80,86 dB. Maka tingkat kebisingan ekuivalen:

$$
L_{e q}=10 \log \left(f 10^{0,1 L}\right)
$$

Dimana fraksi waktu $f$ didapat dari rasio rentang waktu pengukuran sebesar 30 detik dibandingkan waktu total sebesar 150 detik. besar debit maka model curah hujan semakin besar sehingga menghasilkan kebisingan yang semakin besar pula.

Tabel 6. Kebisingan ekuivalen seng gelombang

\begin{tabular}{cccc}
\multirow{2}{*}{$\begin{array}{c}\text { Sudut } \\
\left.\text { Kemiringan ( }{ }^{\circ}\right)\end{array}$} & \multicolumn{3}{c}{ Kebisingan ekuivalen (dB } \\
\cline { 2 - 4 } & $\begin{array}{c}\text { Debit } \\
0,8 \mathrm{lt} / \mathrm{dt}\end{array}$ & $\begin{array}{c}\text { Debit } \\
1,0 \mathrm{lt} / \mathrm{dt}\end{array}$ & $\begin{array}{c}\text { Debit } \\
1,2 \mathrm{lt} / \mathrm{dt}\end{array}$ \\
\hline 10 & 73.87 & 75.13 & 76.47
\end{tabular}




\begin{tabular}{llll}
20 & 72.63 & 73.95 & 75.69 \\
30 & 71.54 & 72.47 & 74.21 \\
40 & 69.99 & 71.19 & 73.23 \\
\hline
\end{tabular}

Tabel 7. Kebisingan ekuivalen plastik gelombang

\begin{tabular}{cccc}
\hline \multirow{2}{*}{$\begin{array}{c}\text { Sudut } \\
\text { Kemiringan }\left({ }^{\circ}\right)\end{array}$} & \multicolumn{3}{c}{ Kebisingan ekuivalen $(\mathrm{dB})$} \\
\cline { 2 - 4 } & $\begin{array}{c}\text { Debit } \\
0,8 \mathrm{lt} / \mathrm{dt}\end{array}$ & $\begin{array}{c}\text { Debit } \\
1,0 \mathrm{lt} / \mathrm{dt}\end{array}$ & $\begin{array}{c}\text { Debit } \\
1,2 \mathrm{lt} / \mathrm{dt}\end{array}$ \\
\hline 10 & 72.85 & 74.46 & 75.87 \\
20 & 71.73 & 73.73 & 75.15 \\
30 & 70.25 & 71.94 & 72.35 \\
40 & 68.97 & 70.27 & 71.15 \\
\hline
\end{tabular}

Grafik hasil penelitian juga menunjukkan bahwa kebisingan rata-rata maksimum terjadi pada pada atap seng gelombang dengan sudut kemiringan $10^{\circ}$ dan debit aliran $1,2 \mathrm{lt} / \mathrm{dt}$ yaitu sebesar $83,46 \mathrm{~dB}$. Kebisingan rata-rata minimum terjadi pada atap plastik gelombang dengan sudut kemiringan $40^{\circ}$ dan debit aliran $0,8 \mathrm{lt} / \mathrm{dt}$ yaitu sebesar 75,96 dB. Kebisingan ekuivalen maksimum terjadi pada pada atap seng gelombang dengan sudut kemiringan $10^{\circ}$ dan debit aliran 1,2 It/dt yaitu sebesar 76,47 dB. Kebisingan ekuivalen minimum terjadi pada atap plastik gelombang dengan sudut kemiringan $40^{\circ}$ dan debit aliran 0,8 It/dt yaitu sebesar 68,97 dB.

Grafik hasil penelitian pada gambar 5 juga menunjukkan bahwa perbedaan materi atap yang digunakan memberikan efek intensitas bunyi yang berbeda. Atap seng gelombang memiliki kecenderungan penurunan intensitas bunyi yang cenderung lebih rendah pada setiap variasi kemiringan. Pada materi atap plastik gelombang mengalami penurunan nilai intensitas yang lebih signifikan. Plastik gelombang memiliki reduksi gelombang bunyi yang lebih baik daripada seng gelombang.

Berdasarkan acuan tingkat ambang batas kebisingan, hasil eksperimen menunjukkan bahwa model atap plastik gelombang dengan sudut $40^{\circ}$ memiliki tingkat kebisingan yang lebih rendah daripada seng gelombang yaitu dengan nilai tingkat kebisingan rata-rata sebesar 75,96 dan tingkat kebisingan ekuivalen sebesar 68,97 dB. Hal ini disebabkan karena bahan plastik memiliki daya serap terhadap bunyi yang lebih besar dibandingkan dengan bahan seng. Namun perlu diperhatikan, dengan nilai tersebut lama waktu terpapar bunyi dengan intensitas tersebut sebaiknya tidak melebihi 8 jam per hari, hal ini sesuai dengan nilai ambang batas kebisingan mengacu pada Keputusan Menteri Tenaga Kerja No. 51/ KEPMEN/1999.
Ambang batas kebisingan untuk lama paparan 1 jam sebesar $94 \mathrm{~dB}, 2$ jam sebesar 91 dB, 4 jam sebesar $88 \mathrm{~dB}$ dan 8 jam sebesar 85 $\mathrm{dB}$. Mengacu pada ambang batas ini maka data hasil penelitian menunjukkan bahwa semua hasil pengukuran masih pada kondisi relatif aman dimana tingkat kebisingan rata-rata masih lebih kecil dari $85 \mathrm{~dB}$. Tetapi hal ini masih harus dianalisis berdasarkan debit aliran sebagai model curah hujan. Curah hujan yang lebih besar akan menghasilkan kebisingan yang relatif lebih besar dan cenderung lebih berbahaya.

Tetapi jika dibandingkan dengan hasil studi dimana kebisingan stabil di atas $50 \mathrm{dBA}$ menjadi gangguan moderat dan di atas 55 dBA merupakan gangguan serius di rumah, hasil penelitian ini memiliki potensi yang tinggi sebagai gangguan bising yang dapat memberikan pengaruh negatip pada penghuni rumah. Dengan acuan di lingkungan non kerja 55 dBA ditetapkan sebagai tingkat yang aman maka hasil pengukuran penelitian ini juga memiliki potensi resiko yang sama.

Tingkat kebisingan yang diperkenankan di lingkungan rumah tinggal untuk kamar tidur sebesar $25 \mathrm{dBA}$ dan ruang keluarga sebesar 40 dBA juga menunjukkan pola resiko yang relatif serius. Atap seng dan plastik gelombang umumnya dipakai pada bangunan sekunder antara lain dapur dan teras rumah. Hasil penelitian yang menunjukkan angka rata-rata di atas $70 \mathrm{~dB}$ dapat menjadi sumber bising yang merambat ke ruang keluarga dan ruang tidur. Hal ini dapat menganggu para penghuni rumah.

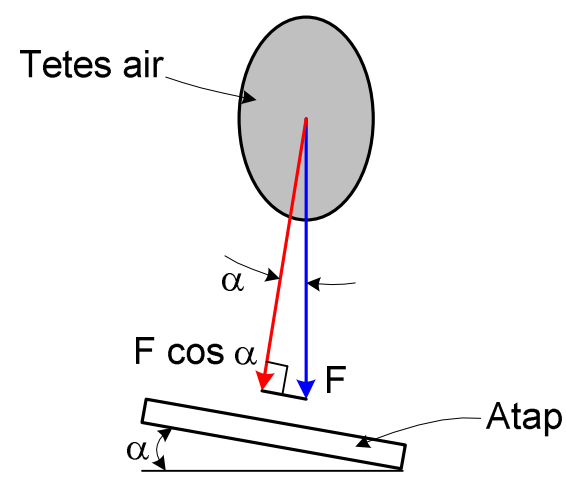

Gambar 6. Model tumbukan tetes air pada atap miring

Fenomena tumbukan tetes air (droplet) pada permukaan atap dengan sudut kemiringan tertentu dapat diilustrasikan dalam gambar 5 . Sebuah tetes air (droplet) akan memiliki gaya sebesar $F$ sebagai gaya yang bekerja karena 
massa tetes air tersebut. Sudut kemiringan atap sebesar $\alpha$ akan memberikan gaya normal yang tegak lurus permukaan datar atap sebesar $\mathrm{F}$ cos $\alpha$. Nilai $\cos \alpha$ akan semakin kecil jika sudut $\alpha$ semakin besar. Nilai ini akan menyebabkan gaya yang menumbuk permukaan atap secara tegak lurus akan menjadi semakin kecil dibandingkan dengan gaya beratnya. Hal ini akan menyebabkan kebisingan sebagai akibat energi tumbukan juga semakin kecil.

Pemodelan tumbukan tetes air seperti gambar 6 telah menunjukkan kesesuaian dengan hasil penelitian. Hasil penelitian menunjukkan bahwa semakin besar sudut kemiringan atap maka tingkat kebisingan yang dihasilkan cenderung semakin kecil. Analisis ini menunjukkan kesesuaian antara hasil eksperimen dan pemodelan tumbukan tetes air pada permukaan atap dengan sudut kemiringan tertentu atau pemodelan secara teoritis.

\section{KESIMPULAN DAN SARAN}

Berdasarkan pembahasan maka dapat diambil kesimpulan sebagai berikut:

1. Semakin besar sudut kemiringan atap maka tingkat kebisingan yang dihasilkan cenderung semakin kecil. Semakin besar debit model curah hujan, kebisingan semakin besar pula.

2. Atap plastik gelombang cenderung menghasilkan tingkat kebisingan lebih rendah dibanding atap seng gelombang.

3. Data hasil penelitian menunjukkan tingkat kebisingan yang relatif aman berdasarkan nilai ambang batas.

\section{UCAPAN TERIMA KASIH}

Disampaikan kepada Dirjen Dikti yang telah mendanai penelitian ini dalam skim Penelitian Dosen Pemula Tahun Anggaran 2015/2016.

\section{DAFTAR PUSTAKA}

Feidihal, 2007, Tingkat kebisingan dan pengaruhnya terhadap mahasiswa di bengkel Teknik Mesin Politeknik Negeri Padang, Jurnal Teknik Mesin Vol. 4 No. 1, p. 31-41, ISSN 1829-8958.

Fredianta D., Huda L.N., Ginting E., 2013 , Analisis tingkat kebisingan untuk mereduksi dosis paparan bising di PT. $X Y Z$, e-Jurnal Teknik Industri FT USU Vol 2, No. 1, p. 1-8

Hopkins C., 2006, Rain noise from glazed and lightweight roofing, Information Paper 2/06, BRE Press, Garston, Watford.

Ikeda H., Yoshida T., Mimura K, 2002, Measuring and predicting rainfall noise- reduction effects of Shizuka-Ace ${ }^{\circledR}$, Furukawa Review, No. 21, p. 81-86.

Jansen H.W., 2004, Rainfall and impact noise measurements on metal roof tiles, TNO Report, Sound and Vibration Division, Stieltjesweg 1, The Netherlands.

Kementrian Sosial RI dan Badan Pusat Statistik, 2012, Analisis data kemiskinan berdasarkan data pendataan Program Perlindungan Sosial (PPLS) tahun 2011.

Kristanto L., Sugiharto $H$, Atmojo AD, Loekito LBD, 2011, Studi reduksi bunyi pada material insulasi atap zincalume, DIMENSI (Journal of Architecture and Built Environment), Vol. 38, No. 2, p. 101-110, ISSN 0126 - 219X.

Munilson J., Edward Y., Al Hafiz, 2014, Gangguan pendengaran akibat bising: tinjauan beberapa kasus, Bagian Telinga Hidung Tenggorok Bedah Kepala Leher, Fakultas Kedokteran Universitas Andalas RSUP Dr. M. Djamil Padang.

Rosadi H.E., Rismansyah N, Fuad F, Setiyowati E, 2012, Pengaruh sudut kemiringan atap bangunan dan orientasinya terhadap kualitas termal, Prosiding Temu IImiah IPLBI 2012.

Satwiko P., 2012. Renovasi akustik gedung konser pascasarjana Institut Seni Indonesia (PS-ISI) Yogyakarta. Jurnal Arsitektur Komposisi. 10(2):119-132.

Sembiring EL, Surbakti MS, 2013, Analisis kebisingan akibat arus lalu lintas di jalan gagak hitam (ring road) medan dan tingkat ketergangguan masyarakat, Teknik Sipil, Universitas Sumatera Utara, Medan.

Setiawan M.F., 2010, Tingkat kebisingan pada perumahan di perkotaan, Jurnal Sipil \& Perencanaan 12(2): 191-200.

Sunarsih E., 2014, Rumah sehat, Kesehatan Lingkungan Pemukiman, Fakultas Kesehatan Masyarakat, Universitas Sriwijaya.

Tukidi, 2010, Karakter curah hujan di indonesia, Jurnal Geografi, Vol. 7 No. 2.

Wafiroh A.H., 2013, Pengukuran tingkat kebisingan di lingkungan SMPN 2 Jember, Skripsi, Jurusan Fisika, Fakultas Matematika dan IImu Pengetahuan Alam, Universitas Jember

Wardle Storeys Blackburn Ltd, 2008, Reducing rain noise on profiled metal roofing systems using DEDPAN ® DS2020 RDV, Durbar Mill, Hereford Road, Blackburn Lancashire BB1 3JU England.

Yermadona H., Yossyafra, Kurniati T, 2013, Pengaruh penerapan zona selamat 
sekolah terhadap tingkat kebisingan lalu lintas di kawasan sekolah kota Padang, TeknikA Vol. 20 No. 2, p. 45-52.

Zikri A., 2014, Struktur atap, Arsitektur Unimal, Lhokseumawe. 